\title{
Studies on Causes Inducing Positive Reaction in Self-Controls of Coombs Tests Carried Out as Cross-Matchings and on Transfusion Results in These Cases
}

\author{
Susumu Okubo, Taeko Sudo, Tomoko Ishida and Kojiro Yasunaga \\ Blood Transfusion Unit of Kansai Medical University Hospital, \\ Moriguchi, Osaka 570 Japan \\ (Received for publication October 27, 1987) \\ Key words : cross-matching, Coombs test, self-control test, antibiotics, plasma preparation \\ products, blood transfusion.
}

\begin{abstract}
Self-control of indirect Coombs tests gave positive results at the frequency of $5.5 \%$ (585 cases) among 10,727 pretransfusion cross-matchings. Drugs (antibiotics, methyldopa) (46.3\%), adsorption of complement along with anti- I (17.8\%), autoantibodies (3.6\%), and anti-A or anti-B $(0.7 \%)$ were the main causes of these positives. On the other hand, no such causes could be found in the remaining $30.8 \%$.

In the 460 cases who received blood transfusion in spite of their positive self-controls, no clinical side effects were obserevd.

\section{Introduction}

Since some media, such as albumin or LISS (low-ionic-strength solution), have been introduced into the Coombs test for pretransfusion cross-matching in order to elevate the sensitivity of the test for the detection of anti-red-blood-cell (RBC) antibodies ${ }^{1)}$, self-control in the Coombs test, using the patient's RBC and their own sera, often gives positive results due to causes other than cold-reactive anti- I, warm-reactive anti-RBC autoantibodies, rouleau formation, or pan-agglutination. Among the probable causes may be anti-RBC antibodies derived from plasma preparation products which had been transfused ${ }^{2)}$, non-specific adsorption of complement along with cold-reactive anti-I antibody or that of plasma proteins to RBC membrane protein ${ }^{3)}$.

Reported here, are the results of studies on the causes inducing self-control positive results in the Coombs test, and also on the side effects of blood transfusions in these cases.
\end{abstract}

\section{Materials and Methods}

Pretransfusion cross-matchings had been carried out in 10,727 cases during the last three 
years, by means of the saline, albumin, Coombs, and bromelin methods. When both the self-control application, using the patient's RBC and his sera, and the accessory application, using the patient's $\mathrm{RBC}$ and donor's sera, gave positive results in the indirect Coombs test (i. C.), the direct Coombs test (d.C.) was performed, and the immunoglobulin class of the antibody was also determined using monospecific antiglobulin or anticomplement sera. Moreover, eluates from the $\mathrm{RBC}$ membrane obtained by Landsteiner's heat method ${ }^{4)}$, the chloroform or trichloroethylene methods ${ }^{5)}$ were examined in order to determine the specificity of the antibody. When the eluate showed no antibody activity, we examined whether or not the patient had received drugs, particularly drugs such as methyldopa, cephems (CEPs), penicillins ( $\mathrm{PCs}$ ), or plasma preparation products during the previous month. Cases who had been administered CEPs or PCs at over three grams per day for more than seven days were also included in this drug-induced classification. Eluation tests were also carried out in cases showing d. C. negative despite their showing self-control positive.

Four hundred and sixty patients among them, who received blood transfusion in spite of the positive control tests, were studied as to side effects following the blood transfusion. For identification of the detected antibodies, three commercialized RBC panels (Ortho Diagnostic Systems Inc., U.S. A., American Dade, U.S. A., and Gamma Biologicals Inc., U.S. A.) and our self-made panel cells were used.

\section{Results}

Five hundred and eighty-five of the 10,727 cases (5.5\%) gave positive results in the selfcontrol i. C. Among them, 218 cases $(37.3 \%)$ also showed a positive d. C. while the remaining 367 cases $(62.7 \%)$ were negative. The majority of these 218 d. C. positive cases, i. e. 134

(61.5\%), gave positive results against both polyspecific anti-human serum (p.s.) and anti-IgG serum, followed by 58 cases $(26.6 \%)$ who were positive against both p.s. and anti-C3, the remaining 26 cases (11.9\%) being positive against p.s., anti-IgG, and anti-C3 serum. Thus, over $70 \%$ of them were positive against anti-IgG serum. In 271 of the 585 cases $(46.3 \%)$, some drugs seemed to lead to a self-control positive i. C. On the other hand, in $9(1.5 \%)$ of the cases, methyldopa had been administered for more than several years, and IgG anti-RBC autoantibodies could be detected in their eluates. In most of the other cases, antibiotics, particularly CEPs $(60.7 \%)$ or PCs $(10.3 \%)$, had been administered individually or in combination (28.6\%), but no anti-RBC autoantibody could be detected in these eluates. The second important cause of the self-control i. C. positives was cold-reactive anti- I antibody or adsorption of complement along with anti- I, which was seen in 104 cases (17.8\%). Furthermore, warm-reactive anti-RBC autoantibody was found to be the cause in 21 cases 


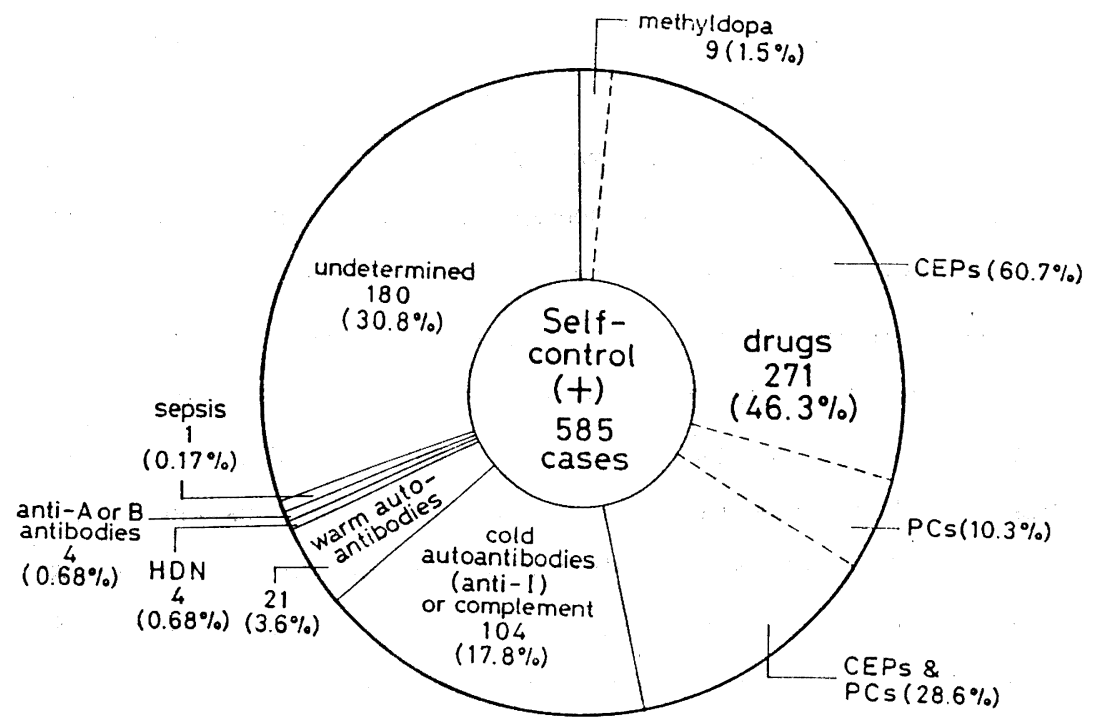

HDN : hemolytic disease of the newborn

Fig. Possible causes inducing self-control positives in the Coombs test

Table. Characteristics of detected antibodies and results of blood transfusion in 460 cases showing self-control positives

\begin{tabular}{|c|c|c|c|c|c|c|c|}
\hline \multirow[t]{2}{*}{ Kind of antibody } & \multirow{2}{*}{$\begin{array}{c}\text { Specificity } \\
\text { on } \\
\text { blood type }\end{array}$} & \multirow{2}{*}{$\begin{array}{l}\text { Globulin class } \\
\text { of antibody }\end{array}$} & \multirow{2}{*}{$\begin{array}{c}\text { No. } \\
\text { of } \\
\text { cases }\end{array}$} & \multicolumn{2}{|c|}{$\begin{array}{l}\text { Characteristics of } \\
\text { detected antibody }\end{array}$} & \multirow[t]{2}{*}{ Transfused RBC } & \multirow{2}{*}{$\begin{array}{l}\text { Side } \\
\text { effect }\end{array}$} \\
\hline & & & & serum & eluate & & \\
\hline \multirow{5}{*}{$\begin{array}{l}\text { Anti-RBC auto- } \\
\text { antibody }\end{array}$} & \multirow{3}{*}{$(+)$} & \multirow{2}{*}{$\lg G$} & 1 & Anti-C & Anti-C & ccDEe & $(-)$ \\
\hline & & & 1 & Anti-M+C+e & Anti-C+e & NN, ccDEE & $(-)$ \\
\hline & & $\lg M+\lg G+C 3$ & 1 & Anti-N & Anti-N & MM & $(-)$ \\
\hline & \multirow{2}{*}{$(-)$} & $\lg G$ & 4 & \multirow{2}{*}{$\begin{array}{l}\text { all panel } \\
\text { cells }(t)\end{array}$} & \multirow{2}{*}{$\begin{array}{l}\text { all panel } \\
\text { cells }(+)\end{array}$} & \multirow{5}{*}{$\begin{array}{l}\text { washed } R B C \text { or red } \\
\text { cell concentrate } \\
\text { with compatible } \\
A B O \& R h \text { type }\end{array}$} & (-) \\
\hline & & $\lg G+C 3$ & 3 & & & & $(-)$ \\
\hline \multirow{3}{*}{ Due to drugs } & \multirow{3}{*}{$(-)$} & $\lg G$ & 2 & "(methyldopa) & $"$ & & $(-)$ \\
\hline & & $\lg G+C 3$ & 134 & \multirow{2}{*}{$\begin{array}{l}\text { all panel } \\
\text { cells }(-) \\
\text { (PCs, CEPs) }\end{array}$} & \multirow{2}{*}{$\begin{array}{l}\text { all panel } \\
\text { cells }(-)\end{array}$} & & $(-)$ \\
\hline & & $\begin{array}{c}\lg M+\lg G+C 3 \\
+C 3 d\end{array}$ & 99 & & & & $(-)$ \\
\hline \multirow{2}{*}{$\begin{array}{l}\text { Anti-A, }-B \text { derived } \\
\text { from plasma pre- } \\
\text { paration }\end{array}$} & \multirow[b]{2}{*}{$(+)$} & \multirow[b]{2}{*}{$\lg G$} & 2 & Anti-A & Anti-A & washed RBC of O type & $(-)$ \\
\hline & & & 2 & $(-)$ & $\begin{array}{l}\text { Anti-A } \\
\text { or } B\end{array}$ & \multirow{2}{*}{$\begin{array}{l}\text { washed RBC or red } \\
\text { cell concentrate } \\
\text { with compatible } \\
\mathrm{ABO} \& \mathrm{Rh} \text { type }\end{array}$} & $(-)$ \\
\hline \multirow{4}{*}{$\begin{array}{l}\text { Cold-reactive } \\
\text { autoantibody }\end{array}$} & \multirow{4}{*}{$(+)$} & $\begin{array}{c}\lg M+\lg G+C 3 \\
+C 4 \\
\end{array}$ & 2 & Anti-1 & Anti-I & & $(-)$ \\
\hline & & $\lg M+C 3+C 4$ & & & & \multirow{4}{*}{$\begin{array}{l}\text { RBC with compati- } \\
\text { ble ABO \& Rh type }\end{array}$} & \multirow{3}{*}{$(-)$} \\
\hline & & $\mathrm{C} 3+\mathrm{C} 4$ & 106 & Anti-1 & $\begin{array}{l}\text { Anti-1 } \\
\text { or }(-)\end{array}$ & & \\
\hline & & $\mathrm{C} 3$ or $\mathrm{C} 4$ & & & & & \\
\hline $\begin{array}{l}\text { Undetermined } \\
\text { (possibly PCs, } \\
\text { CEPs or Anti-A, B) }\end{array}$ & $(-)$ & $\begin{array}{l}\operatorname{Ig} A \\
\lg M \\
\operatorname{Ig} G \\
\text { C3 } \\
\text { C4 }\end{array}$ & 103 & $(-)$ & $(-)$ & & $(-)$ \\
\hline
\end{tabular}

PCs: penicillins, CEPs : cephems 
$(3.6 \%)$, and hemolytic disease of the newborn (HDN) was found in 4 cases $(0.7 \%)$. Anti-A or anti-B antibodies originating from plasma preparation products were found in 4 cases $(0.7 \%)$, and sepsis in 1 case $(0.2 \%)$. In the remaining 180 cases $(30.8 \%)$, no probable causes could be pointed out (Figure).

Although blood transfusions were dared in 460 of the 585 cases showing self-control i. C. positive, no side effects were clinically detectable in any of these cases (Table).

\section{Discussion}

Although the self-control test using the patient's sera and their own RBC is often very useful for analysis of positive results in cross-matchings, it is not always carried out, as it is not always recommended, particularly in pretransfusion cross-matchings $\left.{ }^{6}, 7,8\right)$.

Whenever the self-control test gives a positive result, we should decide how to deal with it as soon as possible, especially in deciding whether to dare or to postpone a blood transfusion.

In this study, the frequency of the positive self-controls was $5.5 \%$. Studies on the causes of the positive reactions revealed that about a half $(46.3 \%)$ of the cases were induced by drugs. Methyldopa is known to produce anti-RBC autoantibody, and the cephems to alter the RBC membrane proteins so as to result in their non-specific adsorption of plasma proteins, and the penicillins to act as haptenes bringing about the production of antibodies combining with the drug-RBC complex. It has been reported that 3 to $5 \%$ or 40 to $75 \%$ of patients who had been administered cephems gave positive results in the d. C. ${ }^{8-14)}$. Moreover, the causative presence of specific anti-penicillin ${ }^{15-17)}$ or of anti-cephem antibodies ${ }^{11,13,14)}$ has also been suggested. And most of our drug-induced positives in the self-control test were considered attributable to antibiotics such as the cephems or penicillins, although the presence of drug-specific antibodies could not yet be clarified.

Since complement adsorption to the $\mathrm{RBC}$ membrane along with cold-reactive antibodies, particularly anti-I antibody, was the second main cause, the test tubes have to be handled speedily and in warm status, to avoid cooling.

As we have reported earlier, commercial heat-treated human albumin or plasma preparation products can contain anti-A and/or anti-B antibodies of the IgG type at high titers ${ }^{2)}$. Here too, IgG anti-A or anti-B antibodies, probably originating from transfused plasma preparation products, could be detected in eluates from the patients' $\mathrm{RBC}$ in 4 cases.

However, in the remaining $30.8 \%$ of the cases showing self-control positive in pretransfusion cross-matching, the cause could not be clarified. Many patients who had been administered with antibiotics or plasma preparation products were found here, too. In these cases, the amount of anti-A or anti-B antibody transferred by the plasma preparation products or of 
$S-30$

proteins adsorbed to the $\mathrm{RBC}$ membrane might be too small to induce a positive Coombs test.

As mentioned above, the administration of drugs, particularly antibiotics and plasma preparation products, seemed to be the main cause of the positive control test. We have to do our best to get thourough clinical information, particularly as to therapies previously received, and to interpret the obtained results of the tests on the basis of this information. On the other hand, the introduction of media, such as LISS or albumin, which enhance the ability of the test in detecting antibodies, may well have elevated the rate of the positive results.

In spite of the positive results of the self-control tests, blood transfusion could be done successfully in 460 cases. Although washed red blood cells were usually used, red cell concentrates were transfused to some of these cases, due to urgency or other reasons, without any side effects.

The self-control test using the patients' $\mathrm{RBC}$ and their own sera should be set up, whenever the direct or indirect Coombs test is carried out for pretransfusion cross-matchings. And, when these self-controls give positive reactions, we should consider the above-mentioned causes.

\section{Conclusion}

The self-control applications of the indirect Coombs test, using the patients' RBC and their own sera, gave positive results at the frequency of $5.5 \%$ among 10,727 pretransfusion crossmatchings carried out in our blood transfusion unit during the past three years.

Drugs such as the cephems or methyldopa, the adsorption of complement to the $\mathrm{RBC}$ membrane along with cold-reactive anti-I antibody, warm-reactive autoantibodies, and anti-A and/or anti-B antibodies originating from plasma preparation products which had been administered were the main causes of positive findings. On the other hand, no such causes could be found in the remaining $30.8 \%$ of the positive cases. Both the recent improvement of the media to enhance the ability of the test in detecting antibodies and the recent increment in the usage of antibiotics or plasma preparation products might be the synergistic cause of the frequent encounters with positive self-control results.

In 460 cases who received blood transfusion in spite of their positive self-control findings, no clinical side effects were observed.

\section{References}

1) Okubo, S., Ishida, T., Okayama, K., Osada, K., Sudo, T. and Yasunaga, K. : Present status of emergency blood transfusion and system of urgent pretransfusion cross-match tests in Kansai Medical University Hospital. J. Kansai Med. Univ. 37(Suppl.), 4 13, 1985.

2) Okubo, S., Ishida, T. and Yasunaga, K. : Studies on anti-erythrocyte antibodies contained in heattreated human plasma protein, albumin and immunoglobulin preparations. Japan J. Clin. Hemat. 26, 
392 398, 1985.

3 ) Swisher, S. N. and Burka, E. R. : pp. 605 610 in Hematology, ed. by Williams, W. J., et al, McGraw-Hill, New York, 1977

4 ) Landsteiner, K. and Miller, G. P. : Serological studies on the blood of the primates. II. The blood groups in anthroid apes. J. Exp. Med. 42, 853 862, 1925.

5 ) Massuet, L. and Armengol, R. : A new method of antibody eluation from red cells using organic solvents. Vox Sang. 39, 343 344, 1980.

6 ) Blood bank : Section V in Inspection Check List \#05. Chicago : College of American Pathologists' Commission on Inspection and Accreditation, 1980.

7 ) Bryant, N.J. : An introduction to immunology. 2nd ed. W. B. Saunders, Philadelphia, 1982.

8 ) Molthan, L., Reidenberg, M. M. and Eichman, M. F. : Positive direct Coombs tests due to cephalothin. New Engl. J. Med. 277, 123 125, 1967.

9 ) Perkins, R. L., Mengel, C. E. and Saslow, S. : Direct Coombs' test reactivity after cephalothin or cephaloridine in man and monkey. Proc. Soc. Exp. Biol. Med. 129, 397 401, 1968.

10) Fass, R. J., Perkins, R. L. and Saslow, S. : Positive direct Coombs' tests associated with cephaloridine therapy. J. A. M. A. 213, 121 123, 1970.

11) Gralnick, H. R., McGinniss, M., Elton, W. and McCurdy, P. : Hemolytic anemia associated with cephalothin. J. A. M. A. 217, 1193 1197, 1971.

12) Sanders, W. E., Johnson, J. E. and Taggart, J.G. : Adverse reactions to cephalothin and cephapirin. Uniform occurrence on prolonged intravenous administration of high doses. New Engl. J. Med. 290, 424 429, 1974.

13) Jeannet, M., Bloch, A., Dayer, J.M., Farquet, J. J., Girard, J.P. and Cruchaud, A. : Cephalothin-induced immune hemolytic anemia. Acta Haemat. 55, 109 117, 1976.

14) Gralnick, H.R., Wright, L.D. and McGinniss, M.H. : Coombs' positive reactions associated with sodium cephalothin therapy. J. A. M. A. 199, 725 726, 1967.

15) Petz, L.D. and Fudenberg, H.H. : Coombs-positive hemolytic anemia caused by penicillin administration. New Engl. J. Med. 274, 171 178, 1966.

16) Swanson, M. A., Chanmougan, D. and Schwartz, R.S. : Immunohemolytic anemia due to antipenicillin antibodies. New Engl. J. Med. 274, 178 181, 1966.

17) White, J.M., Brown, D. L., Hepner, G. W. and Worlledge, S. M. : Penicillin-induced haemolytic anaemia. Brit. Med. J. 3, 26 29, 1968. 